\title{
PENGARUH PROFITABILITAS, LIKUIDITAS, DAN TINGKAT PERTUMBUHAN TERHADAP KEBIJAKAN DIVIDEN PADA PERUSAHAAN MANUFAKTUR
}

\author{
Ni Putu Ayu Sinta Pradnya Sari ${ }^{1}$ \\ Ni Putu Santi Suryantini²
}

\author{
${ }^{1,2}$ Fakultas Ekonomi dan Bisnis Universitas Udayana (Unud), Bali, Indonesia \\ E-mail: sintapradnya29@gmail.com
}

\begin{abstract}
ABSTRAK
Penelitian ini bertujuan untuk mengetahui pengaruhprofitabilitas, likuiditas, dan tingkat pertumbuhan terhadap kebijakan dividen. Populasi penelitian difokuskan pada perusahaan manufaktur di Bursa Efek Indonesia periode 2013-2017 yang berjumlah 139 perusahaan. Berdasarkan kriteria penentuan sampel dengan metodenonprobability sampling dengan teknik purposive samplingdiperoleh sampel berjumlah 22 perusahaan dengan waktu pengamatan selama 5 tahun, sehingga diperoleh jumlah pengamatan sebanyak 110 pengamatan. Teknik analisis yang digunakan dalam penelitian ini adalah analisis regresi linear berganda.Hasil analisis menunjukkan bahwa profitabilitas dan likuiditas berpengaruh positif signifikan terhadap kebijakan dividen pada perusahaan manufaktur di Bursa Efek Indonesia, sedangkan tingkat pertumbuhan berpengaruh negatif signifikan terhadap kebijakan dividen pada perusahaan manufaktur di Bursa Efek Indonesia.
\end{abstract}

Kata kunci:Profitabilitas,likuiditas, tingkat pertumbuhan, kebijakan dividen

\begin{abstract}
This study aims to determine the effect of profitability, liquidity and growth rates on dividend policy. The research population was focused on manufacturing companies in the Indonesia Stock Exchange for the period 2013-2017, totaling 139 companies. Based on the sampling criteria with nonprobability sampling method with purposive sampling technique obtained a sample of 22 companies with a time of observation for 5 years, so that the number of observations obtained as many as 110 observations. The analysis technique used in this study is multiple linear regression analysis. The results of the analysis show that profitability and liquidity have a significant positive effect on dividend policy in manufacturing companies on the Indonesia Stock Exchange, while the growth rate has a significant negative effect on dividend policy in manufacturing companies on the Indonesia Stock Exchange.
\end{abstract}

Keywords: Profitability, liquidity, growth rate, dividend policy 


\section{PENDAHULUAN}

Pasar modal dipandang sebagai salah satu sarana yang efektif untuk menarik dana dari masyarakat yang kemudian akan disalurkan ke sektor-sektor yang produktif. Salah satu upaya investor yaitu melakukan kegiatan pasar modal di beberapa sektor perusahaan di Bursa Efek Indonesia melalui pembelian saham yang ditawarkan ataupun yang diperdagangkan. Semakin banyak perusahaan yang berkembang dapat memberikan pengaruh positif terhadap perekonomian di Indonesia. Untuk itu diperlukan perusahaan yang memiliki kinerja yang baik dan dapat meningkatkan nilai perusahaan, hal tersebut dapat dilakukan melalui keputusan keuangan perusahaan. Keputusan keuangan tersebut meliputi: keputusan investasi, keputusan pendanaan, dan kebijakan dividen (Wiagustini, 2010: 5).

Aktivitas pengambilan keputusan investasi bagi manajemen perusahaan maupun investor harus diperhatikan dan dipertimbangkan dengan benar untuk mengurangi kemungkinan resiko dan ketidakpastian yang akan terjadi. Dalam investasi, investor perlu terus menerus mempelajari berbagai informasi yang berkaitan dengan aktivitas investasinya agar harapan investor dalam melakukan investasi dapat dipenuhi. Investasi merupakan komitmen atas sejumlah dana atau sumber daya lainnya dengan tujuan memperoleh sejumlah keuntungan dimasa yang akan datang (Tandelilin, 2010: 2).

Tujuan utama seorang investor dalam menanamkan dananya adalah untuk memperoleh pendapatan (return), baik berupa pendapatan dividen (dividend yield) maupun pendapatan dari selisih harga jual saham terhadap harga belinya (capital 
gain). Dengan kata lain dapat dikatakan bahwa dividen yang diperoleh merupakan salah satu alasan investor untuk menanamkan dananya pada suatu perusahaan. Dividen merupakan salah satu motivasi untuk menanamkan dana di pasar modal (market security) bagi investor. Investor dapat mengevaluasi kinerja perusahaan dengan menilai besarnya dividen yang dibagikan. Para investor umumnya menginginkan pembagian dividen yang relatif stabil. Stabilitas dividen yang dipertahankan sebuah perusahaan akan berdampak meningkatkan kepercayaan investor terhadap perusahaan, karena akan mengurangi ketidakpastian investor dalam menanamkan dananya (Darmadji dan Fakhruddin, 2012: 2).

Kebijakan dividen merupakan salah satu fungsi keuangan dan tidak terpisahkan dalam keputusan pendanaan perusahaan (Van Horne and Wachowicz, 2008: 270). Kebijakan dividen adalah keputusan keuangan yang telah dilakukan oleh perusahaan setelah perusahaan beroperasi dan memperoleh laba. Kebijakan dividen menyangkut keputusan apakah laba yang diperoleh perusahaan pada akhir tahun akan dibagikan oleh pemegang saham dalam bentuk dividen atau akan ditahan dalam bentuk laba ditahan untuk menambah modal yang akan digunakan sebagai pembiayaan investasi dimasa yang akan datang (Wetson dan Brigham, dalam Sutrisno, 2012: 266).

Kebijakan dividen tergambar pada dividend payout ratio, yaitu persentase laba yang dibagikan dalam bentuk dividen tunai, artinya besar kecilnya dividend payout ratio akan mempengaruhi keputusan investasi pemegang saham dan disisi lain berpengaruh pada kondisi keuangan perusahaaan. Perusahaan yang memilih untuk membagikan laba sebagai dividen akan mengurangi total sumber dana 
Ni Putu Ayu Sinta Pradnya Sari, Pengaruh Profitabilitas,Likuiditas...

internal. Sedangkan perusahaan yang memilih untuk menahan laba yang diperoleh akan mengakibatkan kemampuan pembentukan dana internal yang semakin besar (Sartono, 2010: 281).

Mengingat begitu pentingnya kebijakan dividen yang harus diputuskan oleh perusahaan melalui pemberian dividen kepada para pemegang saham, dimana melalui pembagian dividen akan menambah minat para investor terhadap pembelian saham perusahaan, sehingga perlu dilakukan evaluasi terhadap faktorfaktor kontrol yang menyangkut kebijakan dividen. Faktor-faktor yang mempengaruhi keputusan perusahaan dalam menentukan besarnya laba yang akan dibagikan sebagai dividen antara lain: profitabilitas, liquiditas, dan pertumbuhan perusahaan. Pertimbangan besarnya suatu Dividen Payout Ratio (DPR) diduga berkaitan sangat erat dengan sebuah kinerja manajemen karena kinerja keuangan suatu perusahaan yang cukup bagus dan tentunya bisa diharapkan untuk menentukan besarnya DPR yang sesuai juga dengan harapan para pemegang saham.

Profitabilitas adalah indikator yang digunakan untuk mengukur efektivitas manajemen secara keseluruhan yang ditujukan oleh besar kecilnya tingkat keuntungan yang diperoleh dalam hubungannya dengan penjualan maupun investasi. Semakin baik rasio profitabilitas maka semakin baik menggambarkan kemampuan tingginya perolehan keuntungan perusahaan (Fahmi, 2015: 80). Menurut Latiefasari (2011), apabila tingkat keuntungan tinggi, maka besarnya dividen yang dibayarkan cenderung tinggi, dan sebaliknya bila tingkat keuntungan rendah, maka besarnya dividen yang dibayarkan juga cenderung rendah. 
Menurut Ulfah (2016), salah satu cara untuk meningkatkan kemakmuran bagi pemegang saham, perusahaan perlu menetapkan kebijakan dividen secara optimal, yaitu suatu kebijakan yang menjaga keseimbangan antara peningkatan kemakmuran pemegang saham dengan pertumbuhan nilai perusahaan. Upaya menetapkan kebijakan dividen secara optimal dalam praktiknya sering terjadi hambatan, seperti terjadinya penurunan profitabilitas atau terbukanya kesempatan investasi yang profitable menyebabkan pihak manajemen membatasi pembayaran dividen. Hal ini disebabkan keuntungan yang diperoleh akan dialokasikan menjadi laba ditahan sebagai sumber internal perusahaan. Pihak manejemen berusaha menghindari terjadinya pemotongan dividen atau paling tidak membayar dividen secara tetap atau dikenal dengan nama Stocky Dividend.

Menurut Arifin (2015:35) menyatakan bahwa jika ROA suatu perusahan tinggi maka tingkat perolehan aset atau laba bersih perusahaan pun ikut tinggi yang didapat dari perputaran total investasi perusahaan, dengan begitu akan menaikkan laba perusahaan dan proporsi pembagian dividen akan ikut meningkat, sehingga hal tersebut diperlukan kestabilan dari tingkat profitabilitas perusahaan. Penelitian yang dilakukan oleh Haryetti dan Ekayanti (2012), Marietta dan Sampurno (2013), dan Samrotun (2015) yang menyatakan bahwa return on asset berpengaruh positif secara sangat signifikan terhadap Dividen Payout Ratio.

Likuiditas dari suatu perusahaan merupakan faktor penting yang harus dipertimbangkan sebelum mengambil keputusan untuk menetapkan besarnya dividen yang akan dibayarkan kepada para pemegang saham. Sutrisno (2012: 5) menyatakan semakin kuat posisi kas perusahaan, berarti semakin besar 
Ni Putu Ayu Sinta Pradnya Sari, Pengaruh Profitabilitas,Likuiditas...

kemampuannya untuk membayar dividen. Dengan semakin meningkatnya posisi kas juga dapat meningkatnya keyakinan para investor untuk mendapatkan dividen tunai. Pembagian dividen tersebut dengan pertimbangan bila likuiditas perusahaan baik, tidak melakukan kegiatan investasi yang dapat mengurangi kas dan tidak mempunyai hutang atau sudah memenuhi kewajiban jangka pendeknya.

Likuiditas dapat dihitung dengan current ratio. Rasio ini menunjukkan perbandingan antara aktiva lancar (current assets) dengan hutang lancar (current liabilitties), yang untuk mengetahui kemampuan perusahaan dalam membayar hutang lancar perusahaan. Current ratio yang tinggi memberikan indikasi jaminan yang baik bagi kreditor jangka pendek dalam arti setiap saat perusahaan memiliki kemampuan untuk melunasi kewajiban-kewajiban finansial jangka pendeknya, dengan begitu para pemegang saham akan memperoleh dividen yang tinggi. Akan tetapi current ratio yang tinggi akan berpengaruh negatif terhadap kemampuan memperoleh laba (rentabilitas), karena sebagian modal kerja tidak berputar atau mengalami pengangguran (Harjito dan Martono, 2014: 55). Penelitian yang dilakukan oleh Samrotun (2015) yang menyatakan bahwa likuiditas/current ratio berpengaruh positif dan signifikan terhadap dividend payout ratio.

Pertumbuhan perusahaan dapat dilihat dari pertumbuhan asset yang dimiliki perusahaan dari tahun ke tahun. Menurut Sartono (2010:248) pertumbuhan perusahaan menunjukkan pertumbuhan asset. Pertumbuhan perusahaan dalam penelitian ini diproksikan dengan growth yang merupakan selisih dari total asset perusahaan. Growth menunjukkan pertumbuhan aktiva perusahaan. Aktiva paling sering digunakan untuk aktivitas operasional perusahaan. Pertumbuhan 
perusahaan yang semakin cepat membuat perusahaan membutuhkan banyak biaya untuk membiayai pertumbuhannya. Growth menunjukan pertumbuhan aset, aset merupakan aktiva yang digunakan untuk aktivitas operasional perusahaan.

Menurut Brigham (2011: 211) pertumbuhan perusahaan akan mempengaruhi kebijakan dividen, dimana dengan tingkat pertumbuhan yang baik perusahaan tentunya akan mengalokasikan dana yang didapat perusahaan untuk berinvestasi sehingga akan mengurangi pembagian dividen kepada para pemegang saham. Penelitian yang dilakukan oleh Gill et al. (2010) menyatakan terdapat hubungan negatif antara growth dengan kebijakan dividen. Perbedaan penelitian juga dikemukakan oleh Ahmad dan Vina (2014) yang menyatakan bahwa adanya hubungan positif dan signifikan antara growth terhadap kebijakan dividen.

Penelitian yang dilakukan oleh Haryetti dan Ekayanti (2012) yang menyatakan bahwa pertumbuhan perusahaan yang diukur dengan growth berpengaruh negatif secara signifikan terhadap dividend payout ratio. Munthe (2009), Amidu (2006), dan Al-Kuwari (2009) menyebutkan bahwa pertumbuhan (growth) berpengaruh negatif signifikan dengan kebijakan dividen. Semakin besar tingkat pertumbuhan perusahaan, makin besar dana yang dibutuhkan untuk membiayai pertumbuhannya. Berbeda dengan penelitian Lopolusi (2013) dan Deshkmkh (2005) yang menyatakan growth berpengaruh negatif tidak signifikan terhadap kebijakan dividen. Berbeda dengan penelitian Aivazian (2003) yang menyatakan bahwa growth berpengaruh positif tidak signifikan karena pertumbuhan perusahaan pada penelitian ini tidak dibiayai oleh laba ditahan melainkan dari sumber dana ekstern. 
Ni Putu Ayu Sinta Pradnya Sari, Pengaruh Profitabilitas,Likuiditas...

Perusahaan manufaktur dipilih sebagai objek penelitian dalam penelitian ini dikarenakan perusahaan manufaktur merupakan perusahaan yang memiliki emiten terbesar yang terdaftar pada Bursa Efek Indonesia. Sehingga pengambilan sampel dapat lebih luas dan bervariasi, tidak hanya mencakup dari satu sektor saja. Industri manufaktur terdiri atas tiga sektor yaitu industri dasar \& kimia, sektor aneka industri, dan sektor industri barang konsumsi. PT. Bursa Efek Indonesia menemui masalah seperti beberapa emiten mengabaikan pembagian dividen yang merupakan hak pemegang saham.

Hasil penelitian terdahulu menguji faktor-faktor yang mempengaruhi kebijakan dividen, yang hasilnya kontradiktif dan tidak konsisten. Penelitian tentang pengaruh profitabilitas terhadap kebijakan dividen telah dilakukan oleh Ulfah (2016), profitabilitas tidak berpengaruh signifikan terhadap kebijakan dividen. Namun penelitian ini tidak sejalan dengan penelitian yang telah dilakukan Manneh dan Naser (2015), profitabilitas berpengaruh positif terhadap kebijakan dividen. Penelitian tersebut didukung oleh penelitian yang telah dilakukan Yudiana dan Yadnyana (2016), bahwa profitabilitas berpengaruh positif terhadap kebijakan dividen. Penelitian tentang pengaruh likuiditas terhadap kebijakan dividen dilakukan oleh Kadir (2010), likuiditas tidak berpengaruh terhadap kebijakan dividen. Namun penelitian ini tidak sejalan dengan penelitian yang telah dilakukan oleh Lepolusi (2013), likuiditas berpengaruh negatif terhadap kebijakan dividen. Penelitian tentang pengaruh pertumbuhan perusahaan terhadap kebijakan dividen telah dilakukan oleh Latiefsari (2011), growth berpengaruh negatif terhadap kebijakan dividen. Namun penelitian ini tidak 
sejalan dengan penelitian yang dilakukan oleh Sulistyowati dkk. (2010), bahwa tidak terdapat pengaruh antara variabel growth dengan kebijakan dividen.

Jika dilihat dari data dan teori di atas terjadi phenomena gap, serta penelitian terdahulu menjadi research gap mengenai faktor-faktor yang mempengaruhi kebijakan dividen. Maka perlu dilakukan penelitian lanjutan mengenai faktor-faktor yang mempengaruhi kebijakan dividen. Alasan penentuan variabel-variabel independen tersebut diambil karena dari berbagai penelitian terdahulu terdapat hasil yang tidak konsisten (research gap), dan rasio kebijakan dividen mengalami phenomena gap tahun 2013-2017, sehingga masih perlu dilakukan penelitian kembali terhadap variabel-variabel tersebut.

Profitabilitas dapat dihitung dengan Return On Assets (ROA). ROA ini menunjukkan perbandingan antara laba setelah pajak dengan total aktiva. Rasio ini mencerminkan kemampuan perusahaan dalam menghasilkan laba berdasarkan aktiva yang dimiliki. Menurut Arifin (2015: 35) menyatakan bahwa jika ROA suatu perusahan tinggi maka tingkat perolehan aset atau laba bersih perusahaan pun ikut tinggi yang didapat dari perputaran total investasi perusahaan, dengan begitu akan menaikkan laba perusahaan dan proporsi pembagian dividen akan ikut meningkat, sehingga hal tersebut diperlukan kestabilan dari tingkat profitabilitas perusahaan.

Return on assets menunjukkan kemampuan perusahaan dengan menggunakan seluruh aktiva yang dimiliki untuk menghasilkan laba setelah pajak. Rasio ini penting bagi pihak manajemen untuk mengevaluasi efektivitas dan 
Ni Putu Ayu Sinta Pradnya Sari, Pengaruh Profitabilitas,Likuiditas...

efisiensi manajemen perusahaan dalam mengelola seluruh aktiva perusahaan (Sudana, 2011: 22).

Nilai return on assets yang tinggi akan menunjukkan bahwa perusahaan mampu menghasilkan laba yang relatif tinggi. Investor akan menyukai perusahaan dengan nilai return on assets yang tinggi karena perusahaan dengan nilai return on assets yang tinggi mampu menghasilkan tingkat laba lebih besar dibandingkan perusahaan dengan return on assets rendah, maka perusahaan yang mampu menghasilkan return on assets yang tinggi akan membayar dividen yang tinggi pula (Wati, 2015).

Penelitian yang dilakukan oleh Haryetti dan Ekayanti (2012: 13), Marietta dan Sampurno (2013), dan Samrotun (2015) yang menyatakan bahwa profitabilitas/Return On Asset (ROA) berpengaruh positif secara sangat signifikan terhadap Dividen Payout Ratio (DPR). Beberapa hasil penelitian terdahulu yang mendukung, yaitu hasil penelitian yang dilakukan oleh Al-Nawaiseh (2013) dan Wati (2015) menyatakan bahwa return on assets berpengaruh positif dan signifikan terhadap kebijakan dividen. Return on assets berpengaruh positif dan signifikan terhadap dividend payout ratio ditemukan oleh Chasanah (2008), Marlina dan Clara (2009), Wicaksana (2012), dan Tania (2014).

Berdasarkan teori dan beberapa hasil penelitian empiris tersebut maka dapat dibuat hipotesis penelitian sebagai berikut:

$\mathrm{H}_{1}$ : Profitabilitas berpengaruh positif signifikan terhadap kebijakan dividen pada perusahaan manufaktur di Bursa Efek Indonesia.

Likuiditas perusahaan menunjukkan kemampuan perusahaan dalam melunasi kewajiban-kewajiban finansial jangka pendeknya yang telah disesuaikan 
dengan aset lancar. Oleh sebab itu, bagi perusahaan yang memiliki likuiditas yang baik maka kemungkinan besar pembagian dividen akan baik pula. Likuiditas perusahaan sering dijadikan sebagai alat prediksi untuk memprediksi tingkat pengembalian investasi berupa dividen bagi para investor.

Menurut Samryn (2012: 411), likuiditas adalah kemampuan perusahaan untuk membayar kewajiban-kewajiban jangka pendeknya dengan aktiva lancar. Likuiditas diproksikan dengan rasio lancar (current ratio), yaitu aktiva lancar dibagi hutang lancar. Rasio ini menunjukkan besarnya kas yang dimiliki perusahaan ditambah aset-aset yang dapat berubah menjadi kas dalam waktu satu tahun, relatif terhadap besarnya utang-utang yang jatuh tempo dalam jangka waktu satu tahun,pada tanggal tertentu. Kelebihan rasio ini adalah mempunyai kemampuan untuk memprediksi kebangkrutan yang baik dan dalam proses perhitungan rasio ini mudah dihitung.

Likuiditas dapat dihitung dengan Current Ratio (CR). Rasio ini menunjukkan perbandingan antara aktiva lancar (current assets) dengan hutang lancar (current liabilitties). Rasio ini digunakan untuk mengetahui kemampuan perusahaan dalam membayar hutang lancar perusahaan. Current ratio yang tinggi memberikan indikasi jaminan yang baik bagi kreditor jangka pendek dalam arti setiap saat perusahaan memiliki kemampuan untuk melunasi kewajibankewajiban finansial jangka pendeknya, dengan begitu para pemegang saham akan memperoleh dividen yang tinggi. Akan tetapi current ratio yang tinggi akan berpengaruh negatif terhadap kemampuan memperoleh laba (rentabilitas), karena 
Ni Putu Ayu Sinta Pradnya Sari, Pengaruh Profitabilitas,Likuiditas...

sebagian modal kerja tidak berputar atau mengalami pengangguran (Harjito dan Martono, 2014: 55).

Penelitian yang dilakukan oleh Samrotun (2015) yang menyatakan bahwa likuiditas/Current Ratio (CR) berpengaruh positif dan signifikan terhadap Dividend Payout Ratio (DPR). Menurut Gupta (2010) dalam Lepolusi (2013), semakin baik likuiditas yang dimiliki perusahaan akan meningkatkan kebijakan dividen perusahaan tersebut. Likuiditas yang semakin baik dalam perusahaan mencerminkan bahwa adanya peningkatan kas yang dimiliki perusahaan tersebut. Hanafi dan Halim (2012: 202), apabila penjualan naik, sementara kebijakan piutang tetap, piutang akan naik memperbaiki rasio lancar. Apabila supplier melonggarkan kebijakan kredit mereka, misalkan dengan memperpanjang jangka waktu utang, utang akan naik dan ini akan mengurangi rasio lancar.

Berdasarkan teori dan beberapa hasil penelitian empiris tersebut maka dapat dibuat hipotesis penelitian sebagai berikut:

$\mathrm{H}_{2}$ : Likuiditas berpengaruh positif signifikan terhadap kebijakan dividen pada perusahaan manufaktur di Bursa Efek Indonesia.

Pertumbuhan perusahaan dapat dilihat dari pertumbuhan asset yang dimiliki perusahaan dari tahun ke tahun. Menurut Brigham (2011: 211) pertumbuhan perusahaan akan mempengaruhi kebijakan dividen dimana dengan tingkat pertumbuhan yang baik perusahaan tentunya akan megalokasikan dana yang didapat perusahaan untuk berinvestasi sehingga akan mengurangi pembagian dividen kepada para pemegang saham. Singkatnya, pertumbuhan perusahaan mempunyai pengaruh yang negatif terhadap kebijakan dividen. 
Growth menunjukan pertumbuhan aset dimana asset merupakan aktiva yang digunakan untuk aktivitas operasional perusahaan. Naiknya tingkat pertumbuhan perusahaan maka semakin menurun laba yang dihasilkan akibat dana yang ada digunakan untuk memenuhi biaya operasional. Manajer dalam bisnis perusahaan lebih memperhatikan pertumbuhan untuk menginvestasikan pendapatan setelah pajak dan mengharapkan kinerja yang lebih baik dalam pertumbuhan perusahaan secara keseluruhan. Pertumbuhan aset menggambarkan pertumbuhan aktiva perusahaan yang akan mempengaruhi profitabilitas perusahaan yang meyakini bahwa persentase perubahan total aktiva merupakan indikator yang lebih baik dalam mengukur growth perusahaan (Putrakrisnanda, 2009).

Kebutuhan dana perusahaan meningkat seiring dengan tingginya tingkat pertumbuhan perusahaan. Perusahaan dengan tingkat pertumbuhan yang tinggi akan membutuhkan dana lebih besar dibanding perusahaan yang memiliki tingkat pertumbuhan yang rendah. Oleh karena itu, tingkat pertumbuhan perusahaan merupakan salah satu faktor yang mempengaruhi kebijakan dividen (Sulistiyowati dan Utaminingtyas, 2010). Semakin cepat pertumbuhan perusahaan, maka semakin besar pula dana yang harus dikeluarkan oleh perusahaan. Semakin besarnya dana yang dibutuhkan menyebabkan perusahaan lebih senang menahan labanya daripada membayarkan sebagai dividen. Sehingga, pertumbuhan perusahaan mempunyai hubungan yang negatif terhadap kebijakan dividen.

Penelitian yang dilakukan oleh Haryetti dan Ekayanti (2012) yang menyatakan bahwa pertumbuhan perusahaan yang diukur dengan Growth berpengaruh negatif secara signifikan terhadap Dividend Payout Ratio (DPR). 
Latiefsari (2011) menyatakan bahwa tingkat pertumbuhan (growth)berpengaruh negatif terhadap kebijakan dividen.

$\mathrm{H}_{3}$ : Tingkat pertumbuhan berpengaruh negatif signifikan terhadap kebijakan dividen pada perusahaan manufaktur di Bursa Efek Indonesia.

\section{METODE PENELITIAN}

Penelitian ini dilakukan pada perusahaan manufaktur di Bursa Efek Indonesia periode tahun 2013-2017. Data diperoleh dengan mengakses melalui website: www.idx.co.id. Objek pada penelitian ini adalah kebijakan dividen yang dipengaruhi oleh profitabilitas, likuiditas, dan tingkat pertumbuhan pada perusahaan manufaktur di BEI periode tahun 2013-2017.

Profitabilitas diproksikan dengan return on assets (ROA) adalah laba bersih yang diperoleh perusahaan atas keseluruhan dana yang ditanamkan untuk seluruh kegiatan operasional perusahaan, yang dirumuskan sebagai berikut:

$$
\text { ROA }=\frac{\text { Laba bersih Setelah Pajak }}{\text { Total Aktiva }} \times 100 \%
$$

Likuiditas diproksikan dengan rasio lancar (current ratio) adalah aktiva lancar dibagi hutang lancar, yang dirumuskan sebagai berikut:

$$
\text { Current Ratio }=\frac{\text { Aktiva lancar }}{\text { Utang lancar }} \times 100 \%
$$

Pertumbuhan perusahaan yang diproksikan dengan growth adalah pertumbuhan asset yang dimiliki perusahaan dari tahun ke tahun, yang dirumuskan sebagai berikut:

$$
\text { Growth }=\frac{\text { Total penjualan }_{\mathrm{t}}-\text { Total penjualan }_{\mathrm{t}-1}}{\text { Total penjualan }_{\mathrm{t}-1}} \times 100 \%
$$


Kebijakan dividen yang diproksikan dengan dividend payout ratio adalah suatu keputusan untuk menentukan berapa besar bagian dari pendapatan perusahaan yang akan dibagikan kepada para pemegang saham dan yang akan diinvestasikan kembali atau ditahan di dalam perusahaan, yang dirumuskan sebagai berikut:

$$
\mathrm{DPR}=\frac{\text { Dividend per share }}{\text { Earning per share }} \times 100 \%
$$

Populasi dalam penelitian ini adalah seluruh perusahaan manufaktur di Bursa Efek Indonesia selama periode 2013-2017 yang berjumlah 139 perusahaan. Pemilihan perusahaan manufaktur dipilih karena populasi perusahaan manufaktur adalah paling banyak diantara jenis perusahaan lainya sehingga hasil yang akan didapat nantinya akan mencerminkan karakteristik populasi di Bursa Efek Indonesia, selain itu minimnya aturan atau regulasi dari pemerintah atas kebijakan-kebijakan ekonomi pada perusahaan manufaktur.

Perusahaan manufaktur di Bursa Efek Indonesia pada tahun 2013-2017 sebanyak 139 perusahaan. Sampel yang digunakan dalam penelitian adalah perusahaan manufaktur yang memenuhi kriteria yang digunakan dalam variabel penelitian.

Berdasarkan informasi pada Tabel 1, perusahaan manufaktur di Bursa Efek Indonesia selama periode penelitian berturut-turut dari tahun 2013-2017 adalah 139 perusahaan. Dari proses pemilihan sampel yang telah dilakukan, ditemukan perusahaan manufaktur yang tidak menyampaikan laporan keuangan secara berturut-turut dari tahun 2013 sampai 2017 adalah sebanyak 56 perusahaan. 
Ni Putu Ayu Sinta Pradnya Sari, Pengaruh Profitabilitas,Likuiditas...

Perusahaan manufaktur yang tidak membagikan dividen selama periode 2013 sampai 2017 sebanyak 37 perusahaan. Perusahaan manufaktur yang mengalami penurunan total penjualan dari tahun sebelumnya sebanyak 24 perusahaan. Sehingga sampel penelitian yang diperoleh adalah sebanyak 22 perusahaan. Penarikan sampel dapat dilihat dalam Tabel 1 berikut.

Tabel 1.

Proses Pemilihan Sampel

\begin{tabular}{clc}
\hline No & \multicolumn{1}{c}{ Kriteria } & Jumlah \\
\hline 1 & $\begin{array}{l}\text { Seluruh perusahaan manufaktur di Bursa Efek Indonesia selama periode } \\
\text { penelitian berturut-turut dari tahun 2013 sampai 2017. }\end{array}$ & 139 \\
2 & $\begin{array}{l}\text { Perusahaan manufaktur yangtidak menyampaikan laporan keuangan secara } \\
\text { berturut-turut dari tahun 2013 sampai 2017. }\end{array}$ & $(56)$ \\
3 & $\begin{array}{l}\text { Perusahaan manufaktur yang tidak membagikan dividen selama periode 2013 } \\
\text { sampai 2017. }\end{array}$ & $(37)$ \\
4 & $\begin{array}{l}\text { Perusahaan manufaktur yang mengalami penurunan total penjualan dari tahun } \\
\text { sebelumnya. }\end{array}$ & $(24)$ \\
& $\quad$ Sampel Penelitian & 22 \\
\hline
\end{tabular}

Sumber: Data diolah, 2018

Teknik analisis data dalam penelitian ini adalah analisis regresi linier berganda. Persamaan regresi dalam penelitian ini yaitu:

$$
\mathrm{Y}=\mathrm{a}+\mathrm{b}_{1} \mathrm{X}_{1}+\mathrm{b}_{2} \mathrm{X}_{2}+\mathrm{b}_{3} \mathrm{X}_{3}+\mathrm{e}
$$

Keterangan:

$$
\begin{array}{ll}
\mathrm{Y} & =\text { Variabel dependen (bergantung) } \\
\mathrm{a} & =\text { Koefisien/konstanta regresi } \\
\mathrm{b}_{123} & =\text { Koefisien untuk variabel } \mathrm{X}_{1}, \mathrm{X}_{2} \text {, dan } \mathrm{X}_{3} \\
\mathrm{X}_{123} & =\text { Variabel independen pertama, kedua, dan ketiga } \\
\mathrm{e} & =\text { Error }
\end{array}
$$

\section{HASIL DAN PEMBAHASAN}

Statistik deskriptif penelitian memberikan informasi mengenai karakteristik variabel-variabel penelitian yang terdiri atas jumlah pengamatan, nilai minimum, 
nilai maksimum, nilai rata-rata, dan standar deviasi. Tabel 2 memperlihatkan hasil uji statistik deskriptif sebagai berikut.

Tabel 2.

Statistik Deskriptif Penelitian

\begin{tabular}{cccccc}
\hline & N & Minimum & Maximum & Mean & Std. Deviation \\
\hline ROA & 110 & 0,00 & 7,00 & 0,8182 & 2,03719 \\
CR & 110 & 0,00 & 5,00 & 1,1182 & 1,06428 \\
Growth & 110 & 0,00 & 3,00 & 1,6273 & 0,58825 \\
DPR & 110 & 0,00 & 7,00 & 1,8727 & 1,42783 \\
Valid N (listwise) & 110 & & & & \\
\hline Sumber: Data diolah, 2018 & & & & &
\end{tabular}

Berdasarkan Tabel 2, dapat dijelaskan bahwavariabel bebas profitabilitas $\left(X_{1}\right)$ memiliki nilai minimum sebesar 0,00 dan nilai maksimum sebesar 7,00 dengan nilai mean sebesar 0,8182 dan nilai standar deviasi sebesar 2,03719 dengan jumlah pengamatan sebanyak 110. Dengan nilai mean (rata-rata) profitabilitas perusahaan manufaktur di Bursa Efek Indonesia dari tahun 20132017 sebesar 0,8182 menandakan bahwa dari 110 data pengamatan terdapat 24 pengamatan yang mencapai nilai profitabilitas yang lebih besar dari nilai rata-rata, sedangkan 86 pengamatan lainnya mencapai nilai profitabilitas di bawah nilai rata-rata. Hal ini dapat dikatakan bahwa sebagian kecil perusahaan yang mempunyai kemampuan untuk menghasilkan laba bersih.

Variabel bebas likuiditas $\left(\mathrm{X}_{2}\right)$ memiliki nilai minimum sebesar 0,00 dan nilai maksimum sebesar 5,00 dengan nilai mean sebesar 1,1182 dan nilai standar deviasi sebesar 1,06428 dengan jumlah pengamatan sebanyak 110. Dengan nilai mean (rata-rata) likuiditas perusahaan manufaktur di Bursa Efek Indonesia dari tahun 2013-2017 sebesar 1,1182 menandakan bahwa dari 110 data pengamatan terdapat 69 pengamatan yang mencapai nilai likuiditas yang lebih besar dari nilai 
Ni Putu Ayu Sinta Pradnya Sari, Pengaruh Profitabilitas,Likuiditas...

rata-rata, sedangkan 41 pengamatan lainnya mencapai nilai likuiditas di bawah nilai rata-rata. Hal ini dapat dikatakan bahwa sebagian besar perusahaan yang mempunyai kemampuan untuk membayar kewajiban jangka pendek atau utang yang segera jatuh tempo pada saat ditagih secara keseluruhan.

Variabel bebas tingkat pertumbuhan $\left(\mathrm{X}_{3}\right)$ memiliki nilai minimum sebesar 0,00 dan nilai maksimum sebesar 3,00 dengan nilai mean sebesar 1,6273 dan nilai standar deviasi sebesar 0,58825 dengan jumlah pengamatan sebanyak 110 . Dengan nilai mean (rata-rata) tingkat pertumbuhan perusahaan manufaktur di Bursa Efek Indonesia dari tahun 2013-2017 sebesar 1,6273 menandakan bahwa dari 110 data pengamatan terdapat 103 pengamatan yang mencapai nilai tingkat pertumbuhan yang lebih besar dari nilai rata-rata, sedangkan 7 pengamatan lainnya mencapai nilai tingkat pertumbuhan di bawah nilai rata-rata. Hal ini dapat dikatakan bahwa sebagian besar perusahaan yang akan mengalokasikan dana yang didapat perusahaan untuk berinvestasi sehingga akan mengurangi pembagian dividen kepada para pemegang saham.

Variabel terikat kebijakan dividen (Y) memiliki nilai minimum sebesar 0,00 dan nilai maksimum sebesar 7,00 dengan nilai mean sebesar 1,8727 dan nilai standar deviasi sebesar 1,42783 dengan jumlah pengamatan sebanyak 110 . Dengan nilai mean (rata-rata) kebijakan dividen perusahaan manufaktur di Bursa Efek Indonesia dari tahun 2013-2017 sebesar 1,8727 menandakan bahwa dari 110 data pengamatan terdapat 60 pengamatan yang mencapai nilai kebijakan dividen yang lebih besar dari nilai rata-rata, sedangkan 50 pengamatan lainnya mencapai nilai kebijakan dividen di bawah nilai rata-rata. Hal ini dapat dikatakan bahwa 
sebagian besar perusahaan yang akan membagikan sebagian pendapatan perusahaan kepada para pemegang saham.

Analisis regresi linier berganda digunakan untuk mengetahui besarnya pengaruh Profitabilitas $\left(\mathrm{X}_{1}\right)$, Likuiditas $\left(\mathrm{X}_{2}\right)$, dan Tingkat Pertumbuhan $\left(\mathrm{X}_{3}\right)$ terhadap Kebijakan Dividen (Y). Dalam pengolahan data dengan menggunakan analisis regresi linierberganda, dilakukan beberapa tahapan untuk mencari hubungan antara variabel independen dan variabel dependen. Hasil regresi dapat dilihat pada Tabel 3 berikut.

Tabel 3.

Hasil Analisis Regresi Linier Berganda

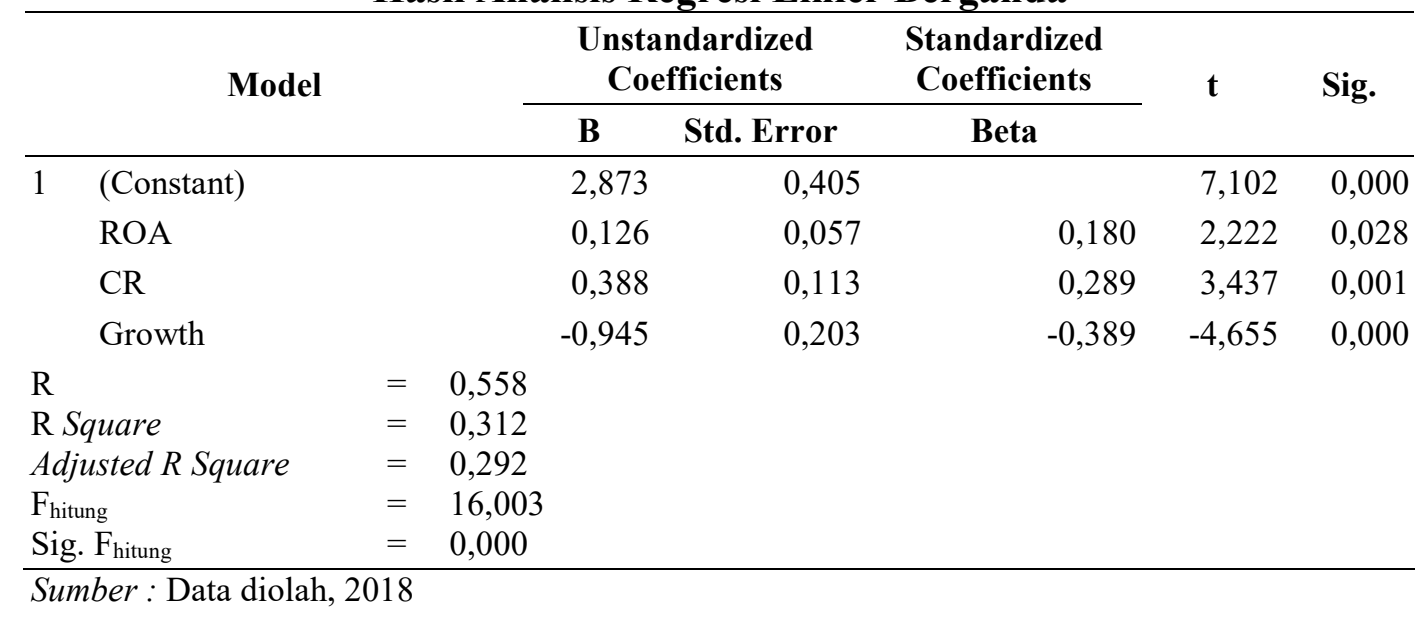

Berdasarkan Tabel 3. dapat diketahui persamaan regresi yang hasilnya sebagai berikut :

$\hat{\mathrm{Y}}=\mathrm{a}+\mathrm{b}_{1} \mathrm{X}_{1}+\mathrm{b}_{2} \mathrm{X}_{2}+\mathrm{b}_{3} \mathrm{X}_{3}+\mathrm{e}$

$\hat{\mathrm{Y}}=2,873+0,126\left(\mathrm{X}_{1}\right)+0,338\left(\mathrm{X}_{2}\right)-0,945\left(\mathrm{X}_{3}\right)+\mathrm{e}$

$\mathrm{a}=2,873$ menunjukkan bahwa jika variabel bebas profitabilitas, likuiditas, dan tingkat pertumbuhan sama dengan nol, maka dividend payot ratio akan mengalami peningkatan sebesar 2,873 persen. 
Ni Putu Ayu Sinta Pradnya Sari, Pengaruh Profitabilitas,Likuiditas...

$\mathrm{b}_{1}=0,126$ berarti jika variabel profitabilitas meningkat satu persen, maka dividend payot ratio akan mengalami peningkatan sebesar 0,126 persen dengan syarat variabel bebas lainnya tetap. $\mathrm{b}_{2}=0,388$ berarti jika variabel likuiditas meningkat satu persen, maka dividend payot ratio akan mengalami peningkatan sebesar 0,388 persen dengan syarat variabel bebas lainnya tetap.

$b_{3}=-0,945$ berarti jika variabel tingkat pertumbuhan meningkat satu persen, maka dividend payot ratio akan mengalami penurunan sebesar 0,945 persen dengan syarat variabel bebas lainnya tetap. $b_{1}$ untuk variabel profitabilitas sebesar 0,126 dengan nilai signifikansi 0,028 yang lebih kecil dari 0,05 sehingga profitabilitas berpengaruh positif signifikan terhadap dividend payot ratio pada perusahaan manufaktur di Bursa Efek Indonesia. Hal ini mengindikasikan bahwa semakin tinggi profitabilitas, maka kebijakan dividen akan semakin meningkat.

$\mathrm{b}_{2}$ untuk variabel likuiditas sebesar 0,338 dengan nilai signifikansi 0,001 yang lebih kecil dari 0,05 sehingga likuiditas berpengaruh positif signifikan terhadap dividend payot ratio pada perusahaan manufaktur di Bursa Efek Indonesia. Hal ini mengindikasikan bahwa semakin tinggi likuiditas, maka kebijakan dividen akan semakin meningkat. $b_{3}$ untuk variabel tingkat pertumbuhan sebesar -0,945 dengan nilai signifikansi 0,000 yang lebih kecil dari 0,05 sehingga tingkat pertumbuhan berpengaruh negatif signifikan terhadap dividend payot ratio pada perusahaan manufaktur di Bursa Efek Indonesia. Hal ini mengindikasikan bahwa semakin

Berdasarkan hasil uji ANOVA pada Tabel 3. dapat diperoleh $F_{\text {hitungsebesar }}$ 16,003 dengan tingkat signifikansi 0,000yang lebih kecil dari 0,05, maka dapat 
disimpulkan bahwa pengaruh profitabilitas, likuiditas, dan tingkat pertumbuhan terhadap kebijakan dividen dalam penelitian ini menunjukkan tingkatan yang baik (good overall model fit) sehingga layak digunakan untuk memprediksi kebijakan dividen. Hasil ini mengindikasikan bahwa naik turunnya kebijakan dividen pada perusahaan manufaktur di Bursa Efek Indonesia tergantung oleh nilai naik turunnya profitabilitas, likuiditas, dan tingkat pertumbuhan perusahaan yang dimiliki oleh perusahaan tersebut. Kebijakan dividen diukur dengan profitabilitas, likuiditas, dan tingkat pertumbuhan.

Berdasarkan Tabel 3. angka AdjustedR Square atau koefisien determinasi sebesar 0,292. Angka ini mengindikasikan bahwa 29,2 persen variasi atau perubahan dalam kebijakan dividen pada perusahaan manufaktur di Bursa Efek Indonesia dapat dijelaskan oleh variasi variabel profitabilitas, likuiditas, dan tingkat pertumbuhan. Sedangkan sisanya sebesar 70,8 persen dijelaskan oleh sebab-sebab lain yang tidak dimasukkan dalam model penelitian.

Koefisien regresi untuk variabel profitabilitas $\left(\mathrm{X}_{1}\right)$ sebesar 0,126 dengan nilai signifikansi 0,028 yang lebih kecil dari 0,05 sehingga profitabilitas $\left(\mathrm{X}_{1}\right)$ berpengaruh positif signifikan terhadap dividend payot ratio $(\mathrm{Y})$ pada perusahaan manufaktur di Bursa Efek Indonesia. Hal ini mengindikasikan bahwa semakin tinggi profitabilitas, maka kebijakan dividen akan semakin meningkat. Dengan demikian hipotesis pertama $\left(\mathrm{H}_{1}\right)$ yang menyatakan bahwa profitabilitas berpengaruh positif signifikan terhadap kebijakan dividen pada perusahaan manufaktur di Bursa Efek Indonesia dapat diterima. Hasil penelitian ini sejalan dengan penelitian yang dilakukan oleh Haryetti dan Ekayanti (2012), Marietta dan 
Ni Putu Ayu Sinta Pradnya Sari, Pengaruh Profitabilitas,Likuiditas...

Sampurno (2013), dan Samrotun (2015) yang menyatakan bahwa profitabilitas/Return On Asset (ROA) berpengaruh positif secara sangat signifikan terhadap Dividen Payout Ratio (DPR). Beberapa hasil penelitian terdahulu yang mendukung, yaitu hasil penelitian yang dilakukan oleh Al-Nawaiseh (2013) dan Wati (2015) menyatakan bahwa return on assets berpengaruh positif dan signifikan terhadap kebijakan dividen. Return on assets berpengaruh positif dan signifikan terhadap dividend payout ratio ditemukan oleh Chasanah (2008), Marlina dan Clara (2009), Wicaksana (2012), dan Tania (2014).

Profitabilitas merupakan elemen penting bagi perusahaan yang berorientasi pada laba. Bagi pimpinan perusahaan profitabilitas dapat dijadikan sebagai tolak ukur untuk mengetahui keberhasilan dari perusahaan yang dipimpinnya, sedangkan bagi investor profitabilitas dapat dijadikan sebagai sinyal dalam melakukan investasi pada suatu perusahaan. Profitabilitas dapat dihitung dengan Return On Assets (ROA). ROA ini menunjukkan perbandingan antara laba setelah pajak dengan total aktiva. Rasio ini mencerminkan kemampuan perusahaan dalam menghasilkan laba berdasarkan aktiva yang dimiliki. Menurut Arifin (2015: 35) menyatakan bahwa jika ROA suatu perusahaan tinggi maka tingkat perolehan aset atau laba bersih perusahaan pun ikut tinggi yang didapat dari perputaran total investasi perusahaan, dengan begitu akan menaikkan laba perusahaan dan proporsi pembagian dividen akan ikut meningkat, sehingga hal tersebut diperlukan kestabilan dari tingkat profitabilitas perusahaan.

Return on assets menunjukkan kemampuan perusahaan dengan menggunakan seluruh aktiva yang dimiliki untuk menghasilkan laba setelah pajak. 
Rasio ini penting bagi pihak manajemen untuk mengevaluasi efektivitas dan efisiensi manajemen perusahaan dalam mengelola seluruh aktiva perusahaan (Sudana, 2011: 22).

Laba merupakan indikator utama yang menunjukkan kapasitas perusahaan dalam membayarkan dividen. Laba tahun berjalan merupakan salah satu faktor yang mempengaruhi pembayaran dividen saat ini selain dividen tahun sebelumnya. Perusahaan penghasil profit mampu membayar dividen sekaligus menyimpan dana internal berupa laba ditahan untuk membiayai investasinya dengan syarat profit yang dihasilkannya cenderung stabil (Marpung dan Hadianto, 2009). Selain itu, hasil penelitian Marpung dan Hadianto (2009), menyatakan bahwa semakin tinggi laba perusahaan maka semakin tinggi aliran kas dalam perusahaan sehingga perusahaan dapat membayar dividen lebih tinggi.

Nilai return on assets yang tinggi akan menunjukkan bahwa perusahaan mampu menghasilkan laba yang relatif tinggi. Investor akan menyukai perusahaan dengan nilai return on assets yang tinggi karena perusahaan dengan nilai return on assets yang tinggi mampu menghasilkan tingkat laba lebih besar dibandingkan perusahaan dengan return on assets rendah, maka perusahaan yang mampu menghasilkan return on assets yang tinggi akan membayar dividen yang tinggi pula (Wati, 2015).

Koefisien regresi untuk variabel likuiditas $\left(\mathrm{X}_{2}\right)$ sebesar 0,338 dengan nilai signifikansi 0,001 yang lebih kecil dari 0,05 sehingga likuiditas $\left(\mathrm{X}_{2}\right)$ berpengaruh positif signifikan terhadap dividend payot ratio $(\mathrm{Y})$ pada perusahaan manufaktur di Bursa Efek Indonesia. Hal ini mengindikasikan bahwa semakin tinggi 
Ni Putu Ayu Sinta Pradnya Sari, Pengaruh Profitabilitas,Likuiditas...

likuiditas, maka kebijakan dividen akan semakin meningkat. Dengan demikian hipotesis kedua $\left(\mathrm{H}_{2}\right)$ yang menyatakan bahwa likuiditas berpengaruh positif signifikan terhadap kebijakan dividen pada perusahaan manufaktur di Bursa Efek Indonesia dapat diterima. Hasil penelitian ini sejalan dengan penelitian yang dilakukan oleh Samrotun (2015) yang menyatakan bahwa likuiditas/Current Ratio (CR) berpengaruh positif dan signifikan terhadap Dividend Payout Ratio (DPR). Menurut Gupta (2010) dalam Lepolusi (2013), semakin baik likuiditas yang dimiliki perusahaan akan meningkatkan kebijakan dividen perusahaan tersebut. Likuiditas yang semakin baik dalam perusahaan mencerminkan bahwa adanya peningkatan kas yang dimiliki perusahaan tersebut.

Likuiditas suatu perusahaan berhubungan erat dengan masalah kemampuan suatu perusahaan untuk memenuhi kewajiban finansialnya yang harus segera dipenuhi. Untuk dapat memenuhi kewajiban tersebut, maka perusahaan harus mempunyai alat-alat likuid yang berupa aktiva lancar yang jumlahnya harus lebih besar dari jumlah kewajiban-kewajiban yang harus segera dipenuhi yang berupa hutang-hutang lancar. Makin besar jumlah aktiva lancar yang dimiliki oleh suatu perusahaan dibandingkan dengan hutang lancar, maka makin besar tingkat likuiditas perusahaan tersebut, sebaliknya apabila jumlah aktiva lancar lebih kecil daripada hutang lancar, berarti bahwa perusahaan tersebut berada dalam likuid. Suatu perusahaan dikatakan memiliki likuiditas yang baik apabila tingkat likuiditas berada diatas standar 1:1. Dengan menentukan tingkat likuiditas yang baik merupakan suatu tindakan hati-hati dari perusahaan dalam mengantisipasi suatu keadaan (Budianas, 2013). 
Likuiditas dapat dihitung dengan Current Ratio (CR). Current Ratio (CR)merupakan rasio yang digunakan untuk mengukur kemampuan perusahaan dalam memenuhi utang atau kewajiban jangka pendeknya (Raharjaputra, 2009: 199) atau yang dikenal dengan istilah likuiditas. Semakin likuid perusahaan berarti semakin besar kemampuan perusahaan untuk memenuhi kewajiban finansial dan telah menggunakan aktiva lancarnya dengan efektif. Hal ini dapat diartikan bahwa ketika perusahaan dalam kondisi likuid maka aktivitas produksi perusahaan akan berjalan lancar sehingga akan menghasilkan laba yang ditargetkan. Semakin besar posisi kas dan likuiditas perusahaan secara keseluruhan, maka akan semakin besar pula kemampuan perusahaan untuk membayar dividen (Sartono, 2010: 293).

Koefisien regresi untuk variabel tingkat pertumbuhan $\left(\mathrm{X}_{3}\right)$ sebesar $-0,945$ dengan nilai signifikansi 0,000 yang lebih kecil dari 0,05 sehingga tingkat pertumbuhan $\left(\mathrm{X}_{3}\right)$ berpengaruh negatif signifikan terhadap dividend payot ratio (Y) pada perusahaan manufaktur di Bursa Efek Indonesia. Hal ini mengindikasikan bahwa semakin tinggi tingkat pertumbuhan, maka kebijakan dividen akan semakin menurun.Dengan demikian hipotesis ketiga $\left(\mathrm{H}_{3}\right)$ yang menyatakan bahwa tingkat pertumbuhan berpengaruh negatif signifikan terhadap kebijakan dividen pada perusahaan manufaktur di Bursa Efek Indonesia dapat diterima. Hasil penelitian ini sejalan dengan penelitian yang dilakukan oleh Haryetti dan Ekayanti (2012) yang menyatakan bahwa pertumbuhan perusahaan yang diukur dengan Growth berpengaruh negatif secara signifikan terhadap 
Ni Putu Ayu Sinta Pradnya Sari, Pengaruh Profitabilitas,Likuiditas...

Dividend Payout Ratio (DPR) dan Latiefsari (2011) menyatakan bahwa tingkat pertumbuhan (growth)berpengaruh negatif terhadap kebijakan dividen.

Pertumbuhan perusahaan dapat dilihat dari pertumbuhan asset yang dimiliki perusahaan dari tahun ke tahun. Menurut Brigham (2011: 211) pertumbuhan perusahaan akan mempengaruhi kebijakan dividen dimana dengan tingkat pertumbuhan yang baik perusahaan tentunya akan megalokasikan dana yang didapat perusahaan untuk berinvestasi sehingga akan mengurangi pembagian dividen kepada para pemegang saham. Singkatnya, pertumbuhan perusahaan mempunyai pengaruh yang negatif terhadap kebijakan dividen.

Kebutuhan dana perusahaan meningkat seiring dengan tingginya tingkat pertumbuhan perusahaan. Perusahaan dengan tingkat pertumbuhan yang tinggi akan membutuhkan dana lebih besar dibanding perusahaan yang memiliki tingkat pertumbuhan yang rendah. Oleh karena itu, tingkat pertumbuhan perusahaan merupakan salah satu faktor yang mempengaruhi kebijakan dividen (Sulistiyowati dan Utaminingtyas, 2010). Semakin cepat pertumbuhan perusahaan, maka semakin besar pula dana yang harus dilekuarkan oleh perusahaan. Semakin besarnya dana yang dibutuhkan menyebabkan perusahaan lebih senang menahan labanya daripada membayarkan sebagai dividen. Sehingga, pertumbuhan perusahaan mempunyai hubungan yang negatif terhadap kebijakan dividen.

Pertumbuhan perusahaan mencerminkan naik atau turunnya tingkat pertumbuhan perusahaan dalam memperoleh laba. Jika semakin tinggi tingkat pertumbuhan perusahaan maka akan semakin besar kebutuhan dana yang dibutuhkan oleh perusahaan tersebut untuk membiayai kebutuhan di masa yang 
akan datang. Hal ini menyebabkan perusahaan yang pertumbuhannya tinggi akan lebih memilih untuk berinvestasi daripada untuk dibagikan sebagai dividen sehingga laba yang diperoleh oleh perusahaan akan dialokasikan sebagai laba ditahan yang ditujukan untuk membiayai pertumbuhan perusahaannya dimasa yang akan datang. Penelitian yang dilakukan oleh Haryetti dan Ekayanti (2012) yang menyatakan bahwa pertumbuhan perusahaan yang diukur dengan growth berpengaruh negatif secara signifikan terhadap Dividend Payout Ratio (DPR).

\section{SIMPULAN DAN SARAN}

Profitabilitas berpengaruh positif signifikan terhadap kebijakan dividen pada perusahaan manufaktur di Bursa Efek Indonesia. Jika ROA suatu perusahaan tinggi, maka tingkat perolehan aset atau laba bersih perusahaan juga ikut tinggi yang didapat dari perputaran total investasi perusahaan, dengan begitu akan menaikkan laba perusahaan dan proporsi pembagian dividen akan ikut meningkat.

Likuiditas berpengaruh positif signifikan terhadap kebijakan dividen pada perusahaan manufaktur di Bursa Efek Indonesia.Current ratio yang tinggi memberikan indikasi jaminan yang baik bagi kreditor jangka pendek, dalam arti setiap saat perusahaan memiliki kemampuan untuk melunasi kewajibankewajiban finansial jangka pendeknya, dengan begitu para pemegang saham akan memperoleh dividen yang tinggi. Tingkat pertumbuhan berpengaruh negatif signifikan terhadap kebijakan dividen pada perusahaan manufaktur di Bursa Efek Indonesia. Semakin cepat pertumbuhan perusahaan, maka semakin besar pula dana yang harus dikeluarkan oleh perusahaan, sehingga menyebabkan perusahaan lebih senang menahan labanya daripada membayarkan sebagai dividen. 
Ni Putu Ayu Sinta Pradnya Sari, Pengaruh Profitabilitas,Likuiditas...

Perusahaan hendaknya mempertimbangkan kondisi keuangan perusahaan sebelum memutuskan untuk membagikan dividen kepada para pemegang saham. Semakin tinggi dividen atau Dividend Payout Ratio (DPR) mencerminkan semakin tinggi kekuatan perusahaan dalam persaingan pasar. Sehubungan dengan hal ini, maka sebaiknya perusahaan meningkatkan dividennya, sehingga investor tertarik melakukan investasi dalam rangka meningkatkan modal dan pada akhirnya berimplikasi terhadap kenaikan dividen perusahaan. Para investor maupun calon investor, terutama yang memiliki tujuan investasi jangka pendek dapat melihat tingkat profitabilitas, likuiditas, dan tingkat pertumbuhan perusahaan untuk dapat mengetahui seberapa besar kemampuan perusahaan untuk membagikan dividen.

Penelitian ini memiliki keterbatasan yang perludiperbaiki pada penelitian selanjutnya. Penelitian ini hanya menggunakan3 faktor yang mempengaruhi kebijakan dividen dan hanya menggunakan lingkup perusahaan manufaktur di Bursa Efek Indonesiasebagai populasi, sehingga belum mampu merepresentasikan seluruhperusahaan di Bursa Efek Indonesia.Untuk itu, diharapkan pada peneliti selanjutnya untuk menambah faktor-faktor yang mempengaruhi kebijakan dividen dan menambah lingkup populasipenelitian tidak hanya pada perusahaan manufaktur, tetapijuga pada sektor-sektor yang lain.

\section{REFERENSI}

Ahmad G.N \& Wardani V.K (2014). The Effect Of Fundamental Factor to Dividend Policy : Evidence in Indonesia Stock Exchange.International Journal of Business and Commerce, 4(2), 14-25.

Ary, Tatang Gumanti. (2013). Kebijakan Dividen: Teori, Empiris dan Implikasi. Yogyakarta: UPP STIM YKPN. 
Brigham, E.F. (2011). Dasar - Dasar Manajemen Keuangan. Edisi 11 Jilid 2. Jakarta: Salemba Empat.

Brigham, E.F. dan Houston, J.F. (2010). Manajemen Keuangan. Jakarta: Erlangga.

Brigham, E. F., dan Houston, J. F. (2015). Fundamentals of Financial Management. Florida: Cengange Learning.

Budianas, N. (2013). Pengertian likuiditas. http://nanangbudi-anas.blogspot.co.id. 2 November (2015) (06:30).

Darmadji, Tjiptono dan Fakhruddin. (2012). Pasar Modal Di Indonesia. Edisi Ketiga. Jakarta: Salemba Empat.

Fahmi, Irham. (2012). Pengantar Pasar Modal. Edisi Pertama. Bandung: Alfabeta.

Gumanti, T. A. (2013). Kebijakan Dividen Teori, Empiris, dan Implikasi, Edisi 1. Yogyakarta: UPP STIM YKPN.

Hanafi dan Halim. (2012). Analisis Laporan Keuangan. Yogyakarta: UPP STIM YKPN.

Harjito, D.A. dan Martono. (2014). Manajemen Keuangan. Edisi kedua. Cetakan Keempat. Yogyakarta: Ekonosia.

Haryetti dan R.A. Ekayanti. (2012). Pengaruh Profitabilitas, Investment Opportunity Set dan Pertumbuhan Perusahaan Terhadap Kebijakan Dividen pada Perusahaan LQ-45 yang Terdaftar di BEI. Jurnal Ekonomi 20 (3): 1-18.

Kadir, A. (2010). Analisis Faktor-Faktor Yang Mempengaruhi Kebijakan Dividen Pada Perusahaan Credit Agencies Do Public di BEI. Jurnal Manajemen dan Akuntansi Vol.11 No.1.

Latiefasari, Hani D. (2011). Analisis Faktor-Faktor Yang Mempengaruhi Kebijakan Dividen. Jurnal Ekonomi Universitas Diponegoro, Semarang, 21 Pebruari (2012).

Lepolusi, I. (2013). Analisis Faktor-Faktor Yang Mempengaruhi Kebijakan Dividen Sektor Manufaktur Yang Terdaftar di BEI Periode 2007-2011. Jurnal Ilmiah Mahasiswa.Vol.2 No.1. Surabaya: Universitas Surabaya.

Raharjaputra, H. S. (2009). Manajemen Keuangan dan Akuntansi: Untuk Eksekutif Perusahaan. Jakarta: Salemba Empat. 
Sartono, A. (2010). Manajemen Keuangan Teori Dan Aplikasi (Ed. ke-4). Yogyakarta: BPFE.

Sudana, I Made. (2011). Manajemen Keuangan Perusahaan: Teori dan Praktik. Surabaya: Erlangga.

Sulistiyowati, Indah., dkk. (2010). Pengaruh Profitabilitas, Leverage, dan Growth terhadap Kebijakan Dividen dengan Good Corporate Governance sebagai Variabel Intervening. Simposium Nasional Akuntansi (SNA) XIII Purwokerto.

Sutrisno. (2012). Manajemen Keuangan Teori, Konsep dan Aplikasi. Yogyakarta: Ekonisia.

Tandelilin, Eduardus. (2010). Portofolio dan Investasi Teori dan Aplikasi. Yogyakarta: Kanisius.

Ulfah, I.F. (2016). Faktor-faktor yang mempengaruhi kebijakan dividen dengan likuiditas sebagai variabel moderasi (studi empiris pada perusahaan yang terdaftar di BEI). Jurnal Akuntansi Vol.4 No.1 Januari 2016, Halaman ISSN (Online): $2338-3593$.

Wiagustini, L.P. (2010). Dasar-Dasar Manajemen Keuangan. Denpasar: Udayana University Press.

Yudiana, I.G.Y., dan Yadnyana, I.K. (2016). Pengaruh Kepemilikan Manajerial, Leverage, Investment Opportunity Set Dan Profitabilitas Pada Kebijakan Dividen Perusahaan Manufaktur. Jurnal Akuntansi Universitas Udayana Vol.15 No.1. 